\title{
Phytophotodermatitis: still a poorly recognised diagnosis
}

\author{
José Eduardo Mateus, ${ }^{1,2}$ Carlos Dias Silva, ${ }^{1,2}$ Mafalda Ferreira, ${ }^{1}$ João Porto ${ }^{1}$
}

IInternal Medicine Department, Centro Hospitalar e Universitário de Coimbra EPE, Coimbra, Portugal

${ }^{2}$ Faculdade de Medicina da Universidade de Coimbra, Coimbra, Portugal

\section{Correspondence to}

Dr José Eduardo Mateus, zeduardomateus@gmail.com

Accepted 27 October 2018

A Check for updates

(c) BMJ Publishing Group Limited 2018. No commercial re-use. See rights and permissions. Published by BMJ.

To cite: Mateus JE, Silva CD, Ferreira $\mathrm{M}$, et al. BMJ Case Rep Published Online First: [please include Day Month Year]. doi:10.1136/bcr-2018 227859

\section{DESCRIPTION}

A 30-year-old man, forestry worker, with no medical history, presented acutely with pruritic erythematous streaks and bullae (figure 1) in linear configuration on his arms. On the previous day he had pruned branches from a fig tree and carried them with his forearms wearing a sleeveless shirt. Symptoms gradually resolved over 4 weeks of topical treatment with clobetasol propionate $0.05 \%$ cream (figure 2 ).

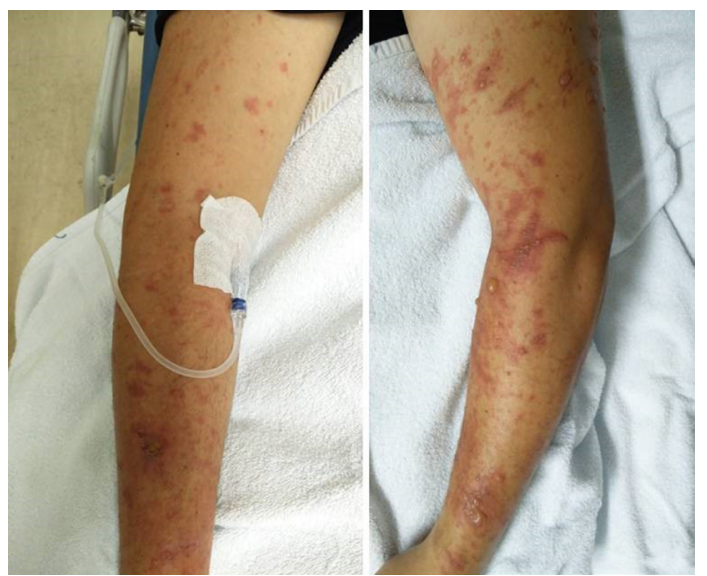

Figure 1 Bullae and irregular pigmented lesions on both arms.
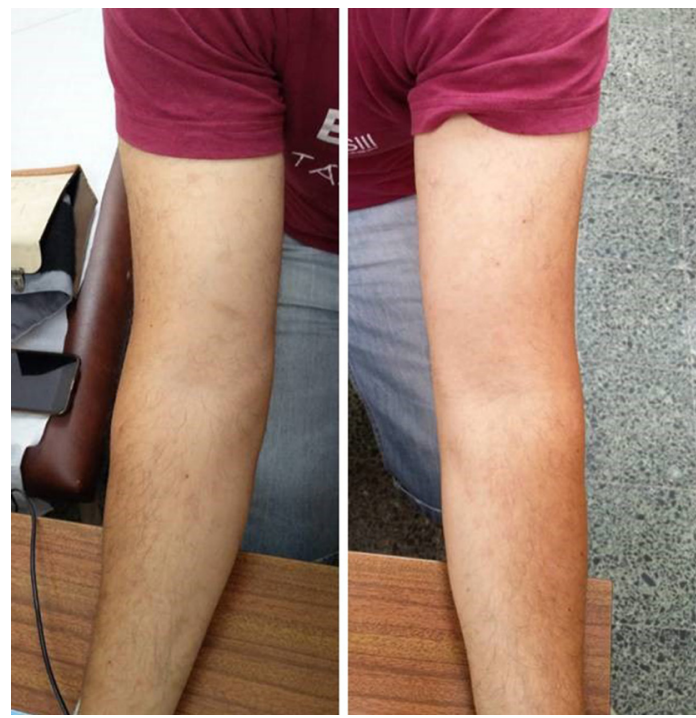

Figure 2 Recovered skin 2 months later.
Furocoumarins are botanical phytoalexins found in a wide variety of plants, including the fig tree (Ficus carita; Moraceae family), which may induce a skin photosensitivity reaction following ultraviolet A radiation exposure. ${ }^{12}$ The acute lesions often present with irregular erythematous streaks or bullae with sharp demarcation between lesional and uninvolved skin. ${ }^{1-3}$ As the acute eruption clears, it is replaced by hyperpigmented macules that may take months to years to resolve. ${ }^{12}$

Although phytophotodermatitis is not infrequent, it occurs most commonly after exposure to limes or other citrus fruits. Though the sap of fig trees can also induce phytophotodermatitis, it is often poorly recognised. Awareness leads to prevention in order to ensure the safety of gardeners, arborists and forestry workers.

\section{Learning points}

- If a sudden erythematous/bullae rash appears in sun-exposed skin, phytophotodermatitis must be suspected.

- The hyperpigmentation stage may take months to years to resolve.

- Phytophotodermatitis is still poorly recognised among gardeners, arborists, forestry workers and health professionals.

Contributors JEM: conception and design of the article acquisition of data, analysis and interpretation of data, drafting the article and approval of the final version. CDS: conception and design of the article, drafting the article, critical revision for important intellectual content and approval of the final version. MF: acquisition of data, analysis and interpretation of data, drafting the article and approval of the final version. JP: conception and design of the article, critical revision for important intellectual content and approval of the final version.

Funding The authors have not declared a specific grant for this research from any funding agency in the public, commercial or not-for-profit sectors.

Competing interests None declared.

Patient consent Obtained.

Provenance and peer review Not commissioned; externally peer reviewed.

\section{REFERENCES}

1 Sasseville D. Clinical patterns of phytodermatitis. Dermatol Clin 2009;27:299-308

2 Reis VMSdos. Dermatoses provocadas por plantas (fitodermatoses). An Bras Dermatol 2010;85:479-89.

3 McGovern TW. Dermatoses due to plants. In: Bolognia JL, Jorizzo JL, Schaffer JV, eds. Dermatology. 3rd edn: Elsevier Saunders:1-273. 
Copyright 2018 BMJ Publishing Group. All rights reserved. For permission to reuse any of this content visit http://group.bmj.com/group/rights-licensing/permissions.

BMJ Case Report Fellows may re-use this article for personal use and teaching without any further permission.

Become a Fellow of BMJ Case Reports today and you can:

- Submit as many cases as you like

- Enjoy fast sympathetic peer review and rapid publication of accepted articles

Access all the published articles

- Re-use any of the published material for personal use and teaching without further permission

For information on Institutional Fellowships contact consortiasales@bmjgroup.com

Visit casereports.bmj.com for more articles like this and to become a Fellow 